\title{
From timely exegesis to contemporary ecclesiology: Relevant hermeneutics and provocative embodiment of faith in a corona-defined world - Generosity during a pandemic
}

\begin{tabular}{|c|c|}
\hline \multicolumn{2}{|c|}{$\begin{array}{l}\text { Author: } \\
\text { Scot McKnight }^{1,2}\end{array}$} \\
\hline \multicolumn{2}{|c|}{$\begin{array}{l}\text { Affiliations: } \\
{ }^{1} \text { New Testament Department, } \\
\text { Northern Seminary, Lisle, USA }\end{array}$} \\
\hline \multicolumn{2}{|c|}{$\begin{array}{l}{ }^{2} \text { Department of New } \\
\text { Testament Studies and } \\
\text { Related Literature, Facu } \\
\text { Theology and Religion, } \\
\text { University of Pretoria, } \\
\text { Pretoria, South Africa }\end{array}$} \\
\hline \multicolumn{2}{|c|}{$\begin{array}{l}\text { Research Project Registration: } \\
\text { Project Leader: } \\
\text { A.G. van Aarde (D) } \\
\text { Project Number: } 2334682\end{array}$} \\
\hline \multicolumn{2}{|c|}{$\begin{array}{l}\text { This research is part of the } \\
\text { research project, 'Biblical } \\
\text { Theology and Hermeneutics', } \\
\text { directed by Prof. Dr Andries } \\
\text { van Aarde, Post Retirement } \\
\text { Professor and Senior Research } \\
\text { Fellow in the Dean's Office, } \\
\text { Faculty of Theology and } \\
\text { Religion, University of Pretoria. }\end{array}$} \\
\hline \multicolumn{2}{|c|}{$\begin{array}{l}\text { Corresponding author: } \\
\text { Scot McKnight, } \\
\text { scotandkris@gmail.com }\end{array}$} \\
\hline \multicolumn{2}{|c|}{$\begin{array}{l}\text { Received: } 17 \text { Dec. } 2020 \\
\text { Accepted: } 19 \text { Feb. } 2021 \\
\text { Published: } 10 \text { May } 2021\end{array}$} \\
\hline \multicolumn{2}{|c|}{$\begin{array}{l}\text { How to cite this article: } \\
\text { McKnight, S., 2021, 'From } \\
\text { timely exegesis to } \\
\text { contemporary ecclesiology: } \\
\text { Relevant hermeneutics and } \\
\text { provocative embodiment of } \\
\text { faith in a corona-defined } \\
\text { world - Generosity during a } \\
\text { pandemic', HTS Teologiese } \\
\text { Studies/Theological Studies } \\
77(4), \text { a6426. https://doi. } \\
\text { org/10.4102/hts.v77i4.6426 }\end{array}$} \\
\hline \multicolumn{2}{|l|}{ Read online: } \\
\hline 口踖回 & $\begin{array}{l}\text { Scan this QR } \\
\text { code with your } \\
\text { smart phone or } \\
\text { mobile device } \\
\text { to read online. }\end{array}$ \\
\hline
\end{tabular}

\begin{abstract}
In a world where economies have no moral conscience, biblical theologians can challenge local cultures with ancient wisdom about generosity and equity. Systemic solutions require changes in the habits of virtue, and this study focuses on the habit of generosity. Building on the work of Stephan Joubert's Paul as Benefactor, this study concentrates on Paul's collection in one notable instance: what he says about generosity in 2 Corinthians 8-9 and, in particular, what he means by isotēs in 2 Cor 8:13-15. Does it mean "equality" or "equity"? Beginning with a reinvigorated interest in the economic vision of the apostle Paul about what is meant by "weak" and "good works" and what the Pastoral Epistles communicate with eusebeia (not "godliness" but "social respectability and civility"), we reconsider the collection as an act on the part of the Pauline mission churches to express more than ecclesial unity. This act embodied a theology of grace in mutual reciprocity and in equitable provision on the part of the wealthy for the poor, not least and not limited to those in their own Christian assemblies. The term isotees is too easily glossed over when translated as "fair balance", "fairness", and so the translation of the term with "equity" or "equality" comes closest to the vision of the apostle. Too few studies on this term baptize it sufficiently in the economics of the ancient world and the early Christian radical vision of siblingship and family.
\end{abstract}

Contribution: From the perspective of the Historical Thought and Source Interpretation of the work of Paul, the question of systemic equality or equity is as crucial to navigating the current economic climate as it has ever been. Equality or equity is not limited to Christian communities but following the early church in embodying a theology of grace.

Keywords: Paul; church; generosity; equality; manna; equity; biblical economies; rich and poor.

Many of us did not lose our jobs during the coronavirus disease 2019 (Covid-19) pandemic, and many of us did. It is a tale of two economies or at least two worlds - the economically buoyant and the economically sinking. I cannot even pretend to be sufficiently informed about economics, especially international economics, and I know that many of us in the theological register like to offer political commentary and opine about economics as if we do understand them. Even Kathryn Tanner, who is (seemingly) more informed about economics than most, in her recent book in which there was much opinion in a negative fashion about capitalism fails to integrate her study into a theory of work or how an individual person or family can live a sustainable, if not also productive, life under the present conditions (Tanner 2019). As one who has thought about this for decades, I can say that most opinions, however, attractive and, however, much we might like the person, simply do not work.

The economy as we encounter is the result of a history of individual persons and collectives over time learning how to 'work together' and bargain and purchase and eat and drink and build and sustain an economically feasible life. I am persuaded that the culture of an economy is not only the result of planning or even a brilliant master idea but also the result of countless decisions more or less agreed upon by more or less the people involved. Thus, neither free enterprise nor socialism has within them, the realities of how people have actually worked together to make life work. Furthermore, the economy is as much a micro-culture of local communities as it is a state or federal production. I am wearied as much by those castigating socialism, which is a sport right

Copyright: (C) 2021. The Authors. Licensee: AOSIS. This work is licensed under the Creative Commons Attribution License.

Note: From timely exegesis to contemporary ecclesiology: Relevant hermeneutics and provocative embodiment of faith in a Coronadefined world - Festschrift for Stephan Joubert, sub-edited by Willem Oliver (University of South Africa). 
now in the USA, as I am by those castigating capitalism, which is also a sport right now in the USA. Solutions then are not likely to come from university libraries as much as they are from local people banding together into a collective that offers a more reasonable and equitable approach to supply and purchase (Wheelan \& Malkiel 2019). I believe that the apostle Paul teaches us how to be a different kind of collective.

So why write about this? My reason has already been hinted at - I believe what we can do as Christians are to forge a new kind of economics at the local level by banding together in what I will call here a more equitable Christian approach to the economy by forming a culture of generosity. One, of course, by suggesting this, is now immediately engaged in local, state, federal and global influential behaviours, and this too is a field fraught with intense debates (eds. Cavanaugh, Bailey \& Hovey 2011; eds. Hovey \& Phillips 2015). I make some suggestions below fully convinced that Christians in the world are not going to come to a consensus, and I do with the awareness that every individual right corresponds to a social, collective duty and that duties and rights are often at odds with another for someone and some collective. My suggestions, of course, come from my study of Scripture and they are focussed on something dear to the heart of Stephan Joubert's own work, the apostle Paul's collection of funds for the poor of Jerusalem (Blanton IV 2017; Blanton IV \& Pickett 2017; Downs 2016b; Joubert 2000; Longenecker 2010; Meggitt 1998; Verbrugge \& Krell 2015). I have written about this in Pastor Paul and will in this context extend the argument of that study as I have shifted my mind somewhat on the breadth of the Pauline concern (McKnight 2019:79-101), but the focus here is pondering how we as Christians ought to conduct ourselves economically during this pandemic, or what we can learn from this pandemic for wise Christian economics.

\section{From 'no interest' to 'great interest'}

I cannot speak for how the apostle Paul has been appropriated or approached in South Africa when it comes to social justice concerns like economic justice, but I can say that in the USA, many are convinced that Paul dropped the potent visions of justice adumbrated by Mary, by Jesus and by the earliest Christians of Jerusalem (cf. Lk 1:46-55; Ac 2:42-47; 4:16-30; 4:32-36; 6:20-26). ${ }^{1}$ Your pressure from apartheid and our pressure from our historic enslavement of Africans and the ongoing poverty of African Americans in our major cities have prompted and provoked many reexaminations of Paul's approach to economics. The most telling citation of this older viewpoint comes from a dean of evangelical New Testaments scholars, Ellis (1989), who once said that:

[L]ike Jesus and the New Testament writers generally, [Paul] displayed no interest in using his ministry for broader humanitarian concerns... and generally saw no obligation as Christ's minister to judge or reform the society of Caesar. (pp. 154-155)

1.I will avoid all discussions about dating these books.
This viewpoint has been defeated in part by Alistair Stewart's revival of the Edwin Hatch thesis that 'bishop' (episkopos) was an economic steward in the Greco-Roman world, and thus, the earliest Christian bishops were tasked with distributing funds for the poor in the assemblies and in wider society (Stewart 2014). Notice the requirements for a bishop in 1 Timothy 3: 'not a lover of money' and the deacon too is to be 'not greedy for money' (v. 3,8), which is affirmed for bishops in Titus 1:7. Money was a concern for the Pastoral Epistles, and one is not speculating too much to say the concern grew from some fertile greed among some of the leaders in the assemblies of Western Asia Minor (Hoag 2015). It appears to me that the bishop was one engaged in distribution of goods.

Stewart has made a singularly valuable suggestion, but Bruce Longenecker has overturned the Ellis line of thinking by arguing that Paul was not only concerned with a kind of 'social' justice for the church that can be called 'ecclesial justice', but Paul's concerns extended beyond the church to economic justice for the poor in the communities where Paul's churches were flourishing (Longenecker 2010:140-155). For many, his exposition requires a fresh reading because for many, the terms in which he sees economic justice are terms that have frequently been read as general do-goodism. Take, to begin with, Acts 20 (all translations in this study are from the New Revised Standard Version unless otherwise stated):

In all this I have given you an example that by such work we must support the weak, remembering the words of the Lord Jesus, for he himself said, 'It is more blessed to give than to receive'. (v. 35)

The term 'weak' (Greek, asthenountōn) is often skipped over in a general care for those in need, but Longenecker's argument is that this term frequently enough refers to the economically weak. Paul made himself economically vulnerable (1 Cor 9:12, 15-18, 22). The same connotation for 'weak' is found in 1 Thessalonians 5:14 if one reads first 5:12-13. Noticeably, the apostle Paul exhorts the Romans to 'contribute to the needs of the saints' and follows that up with 'extend hospitality to strangers' (Rm 12:13). This text suggests economic generosity both to the believers and to non-believers, and this begins to break down the Ellis approach. The same is found with undeniable clarity in Galatians 6:9-10, and here the expression in 6:9 'doing what is right' (Greek, to de kalon poiountes, or 'doing what is excellent') is clarified in 6:10 with 'whenever we have an opportunity, let us work for the good of all, and especially for those of the family of faith'. Once again, doing good or doing what is excellent is common language for economic generosity towards others and the early Pauline churches were to act this way both to those in the faith and those not in the faith. When the apostle tells the Ephesians 4 to 'share with the needy' (v. 28), our instinct need not be with insiders only but with anyone in need. A general exhortation may suggest the same in 1 Timothy 6:18: the rich are 'to do good, to be rich in good works, generous, and ready to share'. There is nothing here suggesting, as Ellis would be suggesting, 
that this is only to be shared only with those in the assemblies. Once again, in Titus 3:14, we have an exhortation to 'good works in order to meet urgent needs', and this too is not limited to believers.

The widows of the Pastoral Epistles are a special case, and again, the evidence, once we filter it through the suggestions above, may well lead us to see early Christian widows as those engaged in economic compassion for anyone in need. Widows are to provide for 'relatives, and especially for family members' (Tm 1 5:8) and they are to be known for 'good works' (another common economic justice term), for 'hospitality' (cf. Rm 12:13), for helping the 'afflicted', a term that can indicate social stress, and all this exhibits being a widow who is 'doing good (!) in every way' (Tm 1 5:10).

Putting this together into a bundle of doing good, we can also consider the Greek term eusebeia that has been far too often translated with 'godliness', and that term evokes Puritanism and private devotion. But Christopher Hoklotubbe has proven that this term is used for public religion and should be translated as 'civilised piety', and one of the distinguishing marks in the Greco-Roman world, not least in Western Asia Minor, was for those marked by such civilised piety to be known for public benevolence, generosity and economic justice (Hoklotubbe 2017).

The old line that the apostle Paul had little to no humanitarian concerns has been overturned by recent research and this same scholarship demonstrates a social conscience on the part of the Pauline mission churches. Yes, his concern was first and foremost with the mission assemblies but not only with them.

\section{The collection for the poor reconsidered}

One of the most fascinating dimensions of the gospel mission of the apostle Paul was his collection for the saints (Downs 2016b; Joubert 2000; Verbrugge \& Krell 2015). Two texts can begin the discussion: (1) In Acts 11:27-30, we learned of a prophetic utterance about a famine that occurred in the days of Claudius and in response 'the disciples determined that according to their ability, each would send relief to the believers [or, "siblings"] living in Judea'. They sent their donation through Barnabas and Saul - clearly is an example of collecting funds for believers in Judea. Acts 12:25 informs us that they accomplished this mission. (2) One could be forgiven for thinking Galatians 2:1-10 is about the same event for it opens with 'I went up again to Jerusalem with Barnabas' (v. 1), but connecting Acts with Galatians has been academic sport for a century or more and need not be played here. Stephan Joubert has made the case that this very text obligated Paul under the custom of reciprocation to generate funds for Jerusalem (Joubert 2000). Whether there were two collections or one is not significant for this context (Downs 2016b:30-72). What does matter is that the Jerusalem siblings 'asked only one thing, that we remember the poor', and the apostle says, 'which was actually what I was eager to do' (Gal 2:10). One could argue from Acts 11:29 that this ministry for the poor was only for the 'siblings' but one can at least suggest that such a restriction may not be in view in the light of Paul's lifelong care for anyone in need.

We turn to (3) 1 Corinthians 16:1-4 where the apostle, in his fraught relationship with the Corinthian assemblies as he sought to mentor leaders and monitor the churches often from across the Aegean in Ephesus, speaks of the 'collection for the saints' (v. 1; peri de tēs logeias tēs eis tous hagious). The term 'saints' has, once again, often been rendered equivalent to Acts 11:29, and there are reasons to do this because the apostle likes to use this term for those who are in Christ. A clear restriction, however, is not obvious from 1 Corinthians $16: 1-4$. What is collected will be taken to Jerusalem when Paul returns with his 'gift'. The most significant text, though short on biographical details, is (4) 2 Corinthians 8-9, which appears to be perhaps two letters of Paul to Corinth motivating them to contribute to his collection for the saints (v. 4; 2 Cor 9:1, 12). It is not to be ignored that the apostle in 9:13 says 'your sharing with them and with all others' (italics mine), and one might genuinely wonder if the 'with all others' is more like Galatians 6:10 than like Acts 11:29. There is perhaps a grammatical point to be made here: the NRSV's 'with all others' has added 'others' for the Greek itself has only 'for all' (eis pantas). This clinches the case that Paul sees this collection for both believers and non-believers who are poor in Jerusalem (Longenecker 2010:140-141, 187, 288). The theme of reciprocity that I will discuss in the next section may tip some against this broader vision of the collection, but the very term 'all' when laid alongside a text like Galatians 6:10 pushes back against the tip!

Perhaps, (5) Romans 15:14-32 is the most penetrating text about the collection for perceiving how Paul himself understood what he was doing. Here, it is clearly seen in priestly terms and the gentiles themselves or their gift is seen as an 'offering' (v. 16) and as a 'ministry to the saints' (v. 25). Again, not unlike Acts 11:29, he speaks of this collection as a donation for 'the poor among the saints at Jerusalem' (v. 26). That 'among' is a rendering of a simple genitive relationship (eis tous ptōchous tōn hagiōn tōn in Yierousalēm), and one could render it 'the devout saints' and thus not give the sense of one group (the poor) inside another group (the saints). I am not persuaded then this text is as much like Acts 11:29 as it is like Galatians 6:10.

One more (6) couplet of texts baffles me in its ambiguity and presses me in classrooms nearly every year to wonder what I think - often because a student asks! Before Felix, we discover that the apostle Paul tells the human that he had gone to Jerusalem 'to bring alms to my nation' (Ac 24:17). One could read this in more than one way: as a generalising expression for generous alms giving in ways that Felix might appreciate, and perhaps, this generalising masks that his gift was actually for believers only. Or, one can read this as what actually happened (for the nation) in spite of original intentions (for believers only). That is, when we read Acts 
21:17-26, it is noticeable for those who care about the collection that nothing is said directly about accepting the donation. We learn that the siblings welcomed the Pauline group and we learn that the elders ask Paul to fund a rite of purification for 'four men' (v. 23). Not a word about the collection. Or is it implied in 21:17's 'warmly' (asmen s)? Or is it possible they did not accept the donation and asked Paul instead to use that money for the purification vows? Or did Paul reroute the donation from the believers in Jesus to 'my nation' as said to Felix at 24:17? The evidence is not as clear as one might like but I lean in the direction, from all this discussion, of seeing the donations from the Pauline churches to have been designed primarily for the believers but that such gifts would have been used as well for anyone in need. Hence, 'my nation' in Acts 24:17 is compatible with the Pauline strategy of economic justice (Gal 2:10), and by this, I mean those with abundance sharing with those who are in need. It is a Christian virtue for the apostle Paul to be generous, and this kind of generosity is both consistent with the Jewish tradition of caring for the poor and in (at times) very serious tension with the general lack of compassion for the poor in the Greco-Roman world (Downs 2016a; Longenecker 2010).

\section{Terms}

The various terms used by the apostle Paul for the collection provide for a solid basis to construct a theology of generosity. There are six terms used: collection (1 Cor 16:1-2), a grace or gift (v. 3; 2 Cor 8:6), a blessing (2 Cor 9:5), a liturgy (v. 12), a service or ministry (Rm 15:31; 1 Cor 16:15; 2 Cor 8:4) and a fellowship ( $\mathrm{Rm} 15: 26)$. If the first focusses a little more on the accounting side, the registering of donations, the others speak more directly into the sort of generosity Paul has in mind.

The most significant element of generosity for Paul is that it begins in an act of God's grace to us in Christ, the act of Christ making himself poor in order to make us rich (2 Cor 8:9) so that we too can use our riches for the sake of relieving the poverty of others (vv. 13-15). Our generosity then is an act of 'reciprocating' grace in that we have been graced by and in Christ so that we can become agents of grace. The term translated with 'gift' in 1 Corinthians 16:3 is the term charis, or 'grace', and this is because 'gift' and 'grace' substantively overlap in reference (Barclay 2015). Barclay's (2015) study of grace as a gift in Pauline theology, taking its cues as it does from the anthropology of gift, and hence, he offers an informed (re)definition of grace:

\section{Grace defined is the:}

[S]phere of voluntary, personal relations, characterized by goodwill in the giving of benefit or favor, and eliciting some form of reciprocal return that is both voluntary and necessary for the continuation of the relationship. In accord with the anthropology of gift, its scope includes various forms of kindness, favor, generosity, or compassion enacted in diverse services and benefits, with the expectation of some reciprocating gratitude or counter-gift. (p. 575)
Grace then is not the giver dropping off a gift at someone's home and forever forgetting about it or the recipient forever forgetting about the giver. Rather, a gift or a grace is the kind of gift that bonds the recipient to the giver in a relationship of reciprocation, however, incongruous and unequal the statuses of the two.

Furthermore, in his study of grace, Barclay sketches six 'perfections' of grace. Grace can be perfected in (1) superabundance, (2) singularity, (3) priority, (4) incongruity, (5) efficacy or (6) non-circularity (Barclay 2015:185). Grace can at times be perfected in non-circularity, which means that the giver is not reciprocated by the recipient. The 'pure grace' movement among some theologians is about this kind of non-circularity. However, by far the more common use of grace, not least in Paul, is that the gift is circular or reciprocating, drawing the recipient (the believer) into praise of God and obedience prompted by the efficacy of that grace. Hence, Paul's logic with grace: if the believer receives a gift from God that believer becomes an agent of grace. That this reciprocation or circularity is at work is found in Romans 15:

[F]or Macedonia and Achaia have been pleased to share their resources with the poor among the saints at Jerusalem. They were pleased to do this, and indeed they owe it to them; for if the Gentiles have come to share in their spiritual blessings, they ought also to be of service to them in material things. (vv. 26-27)

The nodal points then of generosity are:

1. God's gift to us in Christ

2. our reception of that gift

3. our gratitude, devotion, worship and service of God in response

4. our becoming voluntary (2 Cor 9:5) agents of grace to others as we pass on God's grace to us.

This is the foundation for a theology of generosity that promotes economic justice in our world.

' $\mathrm{D}$ ' can be enhanced because for Paul, the generosity exhibited in the collection is also a mutual generosity. The believers of Macedonia and Achaia were delighted, Paul tells the Corinthians - in a way that leads the latter group into motivation by competition, 'to share their resources

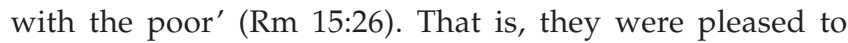
make some of their resources common with one another and with the poor in Jerusalem. The term I use here, 'common', translates koinonia, a term of substantive value in Pauline theology: we have a common life in Christ and as such share a common life together so that our acts of generosity towards others are a form of making common life together (cf. Ac 2:42-47). As such, our acts of common life become a blessing, translated in the NRSV as a 'bountiful gift' (2 Cor 9:5). If the grace or gift is a blessing, it participates (' $\mathrm{A}$ ' and ' $\mathrm{D}$ ' from above) in a pre-eminently act of God. Thus, God is the God of blessing (Eph 1:3). As such we become agents of God for another in providing what others would not otherwise have. 
Two final terms, brought into a neat formula, deserve our attention. 2 Corinthians 9:12 calls the collection a 'rendering of this ministry' (hē diakonia tēs leitourgias tautēs, or literally, the service or ministry of this liturgy). I am persuaded this takes us back to the Ellis-Longenecker discussion above for the second major term here can be rendered 'public act of service'. The term 'service' is ordinary in the Pauline register and draws from the world of household domestics and attendants of those with status. It was flipped downside up by Jesus (Mk 10:45) to become the paradigm for the way of Christ (Phlm 2:6-11). It is, however, the term leitourgia that grabs one's attention. This term, according to standard Greek lexica (Montanari, Garofalo \& Manetti 2015:1225), is used to describe a citizen's public service, in some cases at one's own expense; it also refers to public works at times to public, cultic service and rituals performed. It is, in other words, an act done for the sake of the public by a person from that public (Paul) who embodies generosity. ${ }^{2}$ This term for Paul's collection gets us very close, so I now think, to the Acts 24:17 sense that Paul's collection was used not only for the believers of Jerusalem but also for the common good (Harris 2005:648-649).

Suggestions here and firmer conclusions there lead us to the conclusion that the apostle Paul's collection for the saints embodied a common act on the part of his earliest mission churches, namely using their resources and funds for the poorer members of the assemblies but also for the common good. Which leaves us with a question that can be addressed now: What was the goal? ${ }^{3}$

\section{The aim of generosity}

If not the most radical statement made by Paul, 2 Corinthians $8: 13-15$ is among them. In a recent project of mine to translate the New Testament (McKnight 2022), these three verses became a joyous challenge in choosing which term to use to translate the Greek term isotès. I provide my translation with the critical term underlined:

13 For [this giving] isn't so [financial] leisure [comes] to others [with] trouble for you, but that [the result may be] on the basis of equality. 14 In the present season, your overflow [may meet] their lack, so their overflow may come to your lack - so that there may be equality. 15 Just as it's written: the one [with] much did not magnify and the one [with] little did not diminish.

The thesis of Paul is that one's abundance can be used to meet the need of another, and the aim in both v. 13 and v. 14 is 'equality' (McKnight 2019:94-98). What does the term 'equality' mean in this context? Standard translations vary. The NRSV has 'fair balance', while the NIV (1984, 2011), NLT and the CEB have 'equality' (Edition de Genève, 'égalité')

2.Its etymology points to the work of or for the people (laos, people; ourgia, from ergon, work).

3.Only one theme will be addressed here, but one needs to add here in passing that Paul saw generosity as an act of compassion and relief for the poor (GI 2:10), an expression of ecclesial unity between Jerusalem and the mission churches (GI 2:1-10; Rm 15:26-27) and even worship (1 Cor 16:1-4; 2 Cor 8:23; 9:11-13) (Downs 2016b:120-160). but the ESV has 'fairness'. ${ }^{4}$ The 1912 Luther translation has 'daß es gleich sei' and 'und ein Ausgleich geschehe', which is closer to the English 'same'. The word 'fairness' has its own social history in the USA (Rawls 2001), and recent conversations at the social and political level in the USA prompt a conversation about whether this term means 'equality' or 'equity', the former being closer to 'the same' and the latter towards 'fairness as a result of economic, political adjustment'.

Three standard lexica definitions can open up a pathway for us. Firstly, J.P. Louw, in his listing of 'Same or Equivalent Kind or Class', has for our term 'the state of being equal - 'equality' (in the sense of having equal features or characteristics)' and translates our passage with 'equality'(eds. Louw \& Nida 1988:1589). Ceslaus Spicq's careful analysis of this term concludes that the term means 'equality' (Spicq 1995:223-232). Franco Montanari's translations include 'equality' and 'equity, impartiality' and 'identical form, equidistance' (Montanari et al. 2015:990). The lexica tradition clearly indicates a translation along the line of 'equality'. What to make of this? Does the apostle Paul think the believers in Corinth and in Jerusalem should have the same amount of food and money and shelter?

If we turn to the use of this term and its word group in the New Testament as a sampling of meaning, we are forced to turn immediately to Colossians 4:1 where the apostle Paul taught the slave owners of Colossae to treat their slaves with to dikaion kai tēn isotèta. One could soften the translation, as the NRSV does, with 'justly and fairly', while the NIV 2011 has 'right and fair'. The former term connotes justice according to either Torah or to life in the Spirit in the way of Christ (Gorman 2009, 2015), which is deeper than even 'justice' but the second term is our concern. What does it mean to treat one's slave with isotess? I suggest that for this, we turn to the contemporary letter of Paul's, to Philemon, and head straight to the words Paul has for the slave owner about how he is treated Onesimus upon his return (McKnight 2017). The words are found vv. 15-18, which I quote here from my own translation:

15 For perhaps because of this he was separated for an hour so you might possess him for Era, 16 no longer as a slave but, above a slave, as a loved brother, especially for me but even more for you, both in the flesh and in the Lord. 17 Therefore, if you have me as common life, receive him as me. 18 If he wronged you or owes anything, calculate this to me.

Onesimus, the standard reading goes, has become a believer in the context of Paul's imprisonment, Paul is sending him back to his slave owner, but there is a powerful theology at work in how Philemon is to respond. What has happened the apostle credits to providence (v. 15), but Onesimus is now a sibling, and therefore, he should be welcomed back 'no longer as a slave but, above a slave, as a loved brother' (v. 16).

4.Abbreviations of Bible translations: New Revised Standard Version (NRSV); English Standard Version (ESV); New International Version (NIV); New Living Translation (NLT); Common English Bible (CEB). 
Paul registers an argument with Philemon that is theological: this is about their 'common life' in Christ and how Philemon responds to Onesimus is how he responds to Paul himself (v. 17), and Paul will make good on his side by paying for anything Onesimus owes (v. 18). This must be what the apostle means by isotēs in Colossians 4:1. What Paul means in the Colossae situation is 'equal status in Christ as siblings', which does not entirely erase distinctions or even hierarchies for after all the older brother had some status, the younger children in a family did not have (Trebilco 2012). Yet, 'equal status in Christ as siblings' takes us into the heart of the Pauline communities.

Other texts in the NT shed some light on this basic definition: the son is equal with the father or God in John 5:18 and Philippians 2:6 and we all have the same Spirit (Ac 11:17), while that most challenging of Jesus' parables shows that some thought that the equal pay was not fair (Mt 20:12). If we move towards 'equal status in Christ as siblings', the use of the word group in the New Testament pushes us closer to equality than simply to equity or fairness with adjustments.

If we recall our discussion of the collection as gift above and take into consideration this sense of $i s o t \bar{s} s$, we have fresh ideas both for reading 2 Corinthians 8:13-15 and how Christians today can become generous in a Pauline sense. A few observations now to close this offering to our friend Stephan Joubert. The issue at hand is the lack of provisions in Jerusalem on the part of the poor and the abundance of resources in Corinth (v. 14). Furthermore, there is a strong sense of reciprocation in the Pauline theology of grace and gift: our A-D pattern above can be repeated here. A: God's gift to us in Christ; B: Our reception of that gift; C: Our gratitude, devotion, worship and service of God in response; D: Our becoming voluntary (2 Cor 9:5) agents of grace to others as we pass on God's grace to us. Paul's theology of generosity is based on divine grace and human transformation as those experiencing that grace become agents of giving ( $\mathrm{Rm} \mathrm{15:27;} 2$ Cor 8:9, 13-15; 9:7-15). This sense of reciprocation has been analysed in Joubert (2000) and now in Barclay (2015). By appealing to the kind of reciprocal benevolence so typical in the ancient world, essayed as it was in Seneca's On Benefits, Joubert is right to point us all towards the sense of obligation that Paul is putting into his rhetoric while denying it! That is, Paul can speak against 'compulsion' (2 Cor 9:7) while using the sense of social bonding's obligation at the same time.

What remains is for us to observe is that Paul cites the Exodus 16 manna text to buttress his appeal and sense of isotess (2 Cor $8: 15)$. In the manna text, to go straight to the point, each person was to take God's provision for what the person needed and for what the family needed - no more, no less. What we have here is a brilliant illustration by Paul: each person is to have what one needs and the Christian community is to ensure that this occurs among the siblings. But because Paul's sense of generosity for those in need transcends the siblings, even if it starts there and often because of pressing poverty among the believing giver
(Longenecker 2010:291), one must think the apostle Paul believed that the Christians were to embody a new economics of generosity that included some in the wider community. Those of us who take Paul's words in our scriptures as a guide for life will do well, then, to think about economics in terms of generosity first for the household of faith but, when possible, also for the common good. ${ }^{5}$ While the term 'equity' is a solid translation of 2 Corinthians 8:13, 14, the term 'equality' is closer to Paul's aim.

\section{Acknowledgements Competing interests}

The author declares that he has no financial or personal relationships that may have inappropriately influenced him in writing this article.

\section{Author's contributions}

S.M. is the sole author of this study.

\section{Ethical consideration}

This article followed all ethical standards for research without direct contact with human or animal subjects.

\section{Funding information}

This research received no specific grant from any funding agency in the public, commercial or not-for-profit sectors.

\section{Data availability}

Data sharing is not applicable to this article as no new data were created or analysed in this study.

\section{Disclaimer}

The views and opinions expressed in this article are those of the author and do not necessarily reflect the official policy or position of any affiliated agency of the author.

\section{References}

Barclay, J.M.G., 2015, Paul and the gift, Wm. B. Eerdmans, Grand Rapids, MI.

Blanton, IV, T.R., 2017, A spiritual economy: Gift exchange in the letters of Paul of Tarsus, Yale University Press, New Haven, CT.

Blanton, IV, T.R. \& Pickett, R., 2017, Paul and economics: A handbook, T.R. Blanton IV (ed.), Fortress, Minneapolis, MN

Cavanaugh, W.T., Bailey, J.W. \& Hovey, C. (eds.), 2011, An Eerdmans reader in contemporary political theology, Wm. B. Eerdmans, Grand Rapids, MI.

Downs, D.J., 2016a, Alms: Charity, reward, and atonement in early Christianity, Baylor University Press, Waco, TX.

Downs, D.J., 2016b, The offering of the Gentiles: Paul's collection for Jerusalem in its chronological, cultural, and cultic contexts, Wm. B. Eerdmans, Grand Rapids, MI.

Ellis, E.E., 1989, Pauline theology: Ministry and society, Wm. B. Eerdmans, Grand Rapids, MI.

Gorman, M.J., 2009, Inhabiting the cruciform God: Kenosis, justification, and theosis in Paul's narrative soteriology, Wm. B. Eerdmans, Grand Rapids, MI.

Gorman, M.J., 2015, Becoming the Gospel: Paul, participation, and mission, Wm. B. Eerdmans, Grand Rapids, MI.

5.1 have shifted from my earlier phrasing of this (McKnight 2019:100-101), but I do think that the ecclesiocentric nature of generosity was uppermost in Paul's mind and practice. 
Harris, M.J., 2005, The second Epistle to the Corinthians, NIGTC, Wm. B. Eerdmans, Grand Rapids, MI.

Hoag, G.G., 2015, Wealth in ancient Ephesus and the first letter to Timothy: Fresh insights from Ephesiaca by Xenophon of Ephesus, Eisenbrauns, Winona Lake, IN.

Hoklotubbe, T.C., 2017, Civilized piety: The rhetoric of pietas in the pastoral epistles and the Roman Empire, Baylor University Press, Waco, TX.

Hovey, C. \& Phillips, E. (eds.), 2015, The Cambridge companion to Christian political theology, Cambridge University Press, New York, NY.

Joubert, S., 2000, Paul as benefactor: Reciprocity, strategy and theological reflection in Paul's collection, WUNT 2.124, Mohr Siebeck, Tübingen.

Longenecker, B.W., 2010, Remember the poor: Paul, poverty, and the Greco-Roman world, Wm. B. Eerdmans, Grand Rapids, MI.

Louw, J.P. \& Nida, E.A. (eds.), 1988, Greek-English Lexicon of the New Testament: Based on semantic domains, vol. 2, 2nd edn., Fortress, New York, NY.

McKnight, S., 2017, The letter to Philemon, NICNT, Wm. B. Eerdmans, Grand Rapids, MI.

McKnight, S., 2019, Pastor Paul: Nurturing a culture of Christo formity in the church, Theological Explorations for the Church Catholic, Brazos, Grand Rapids, MI.
McKnight, S., 2022, The Second Testament: A new Translation, InterVarsity Press, Downers Grove, IL.

Meggitt, J., 1998, Paul, poverty and survival, SNTW, T\&T Clark, Edinburgh.

Montanari, F., Garofalo, I. \& Manetti, D., 2015, The Brill dictionary of Ancient Greek, bilingual edn., M. Goh \& C. Schroeder (eds.), Brill, Boston, MA.

Rawls, J., 2001, Justice as fairness: A restatement, 2nd edn., E.I. Kelly (ed.), Harvard Belknap Press, Cambridge, MA.

Spicq, C., 1995, Theological lexicon of the New Testament, vol. 3, transl. J.D. Ernest, Hendrickson, Peabody, MA.

Stewart, A.C., 2014, The original Bishops: Office and order in the first Christian communities, Baker Academic, Grand Rapids, ML.

Tanner, K., 2019, Christianity and the new spirit of Capitalism, Yale University Press, New Haven, CT.

Trebilco, P., 2012, Self-designations and group identity in the New Testament, Cambridge University Press, Cambridge.

Verbrugge, V. \& Krell, K.R., 2015, Paul and money: A biblical and theological analysis of the Apostle's teachings and practices, Zondervan, Grand Rapids, MI.

Wheelan, C. \& Malkiel, B.G., 2019, Naked economics: Undressing the dismal science, 3rd edn., W. W. Norton, New York, NY. 